\title{
Izračun vodne bilance tehtalnega lizimetra za oceno napajanja vodonosnika
}

\author{
Špela ŠERJAK ${ }^{1}$, Vesna ZUPANC ${ }^{2}$, Barbara ČENČUR CURK ${ }^{3}$
}

Received September 04, 2019; accepted October 28, 2019. Delo je prispelo 04. septembra 2019, sprejeto 28. oktobra 2019.

\begin{abstract}
Izračun vodne bilance tehtalnega lizimetra za oceno napajanja vodonosnika

Izvleček: Ljubljansko polje je pomemben vodonosnik, ki je vir pitne vode za širšo okolico Ljubljane, zato je poznavanje vodne bilance zelo pomembno. Pri tem je ključno poznavanje dinamike toka vode skozi nezasičeno cono ter načina napajanja vodonosnika. $\mathrm{Z}$ oceno vodne bilance dobimo vpogled, kako se napaja vodonosnik in obnavlja podzemna voda. S pomočjo vgrajenega monolitnega tehtalnega lizimetra v Klečah v Ljubljani smo ocenili vodno bilanco za hidrološko leto od marca 2014 do februarja 2015. Pri izračunu smo uporabili meritve mase lizimetra in iztoka ter padavine in dejansko evapotranspiracijo, izračunane iz spremembe mase lizimetra. Večje padavinske dogodke smo razvrstili po času trajanja, intenziteti ter količini padavin. Meritve padavin kažejo, da je bilo obravnavano obdobje izjemno mokro. Padavine so v izbranem hidrološkem letu prispevale k pozitivni vodni bilanci zgornjega sloja nezasičene cone in k napajanju Ljubljanskega vodonosnika na območju vodarne Kleče.

Ključne besede: vodna bilanca; napajanje vodonosnika; monolitni tehtalni lizimeter; Ljubljansko polje; nezasičena
\end{abstract} cona
Calculation of water balance of the weighing lysimeter for assessment of aquifer recharge

Abstract: Ljubljana field aquifer is an important source of drinking water for the Ljubljana city and surrounding areas. Knowledge of the water balance and of the water flow dynamics through the unsaturated zone and recharge of Ljubljana field aquifer is crucial. The water balance assessment of the upper unsaturated zone provides an insight into groundwater recharge and renewal. With the help of build-in monolith weighing lysimeter in Kleče in Ljubljana we have assessed the water balance for hydrological year from March 2014 to February 2015. Water balance parameters, precipitation and evapotranspiration were determined from the changes in the mass of lysimeter and outflow tank. Precipitation events were evaluated based on their duration, intensity and the amount of precipitation. Evapotranspiration and the duration of precipitation were estimated based on the changes of the lysimeter mass. Results show that the chosen period was extremely wet. In the selected hydrological year, precipitation contributed to positive water balance of the upper unsaturated zone, as well as to the recharge of the aquifer.

Key words: water balance; groundwater recharge; monolithic weighing lysimeter; Ljubljansko polje; unsaturated zone

\footnotetext{
1 spela.serjak@gmail.com

2 Univerza v Ljubljani, Biotehniška fakulteta, Oddelek za agronomijo, Jamnikarjeva 101, 1000 Ljubljana, vesna.zupanc@bf.uni-lj.si

3 Univerza v Ljubljani, Naravoslovnotehniška fakulteta, Oddelek za geologijo, Aškerčeva cesta 12, 1000 Ljubljana, barbara.cencur@ntf.uni-lj.si

Prispevek je del magistrske naloge Špele Šerjak pod mentorstvom doc. dr. Barbare Čenčur Curk in doc. dr. Vesne Zupanc.
} 


\section{UVOD}

V zadnjih letih so vse bolj aktualne raziskave vpliva urbanega okolja na količino in kakovost podzemne vode (Meissner in sod., 2007). Raziskave so usmerjene $\mathrm{v}$ določanje količinskega stanja podzemne vode, način napajanja ter obnavljanja vodonosnikov. Poznavanje mehanizmov napajanja vodonosnika je zelo pomembno za upravljanje in varovanje podzemnih vodnih virov. Izračuni členov vodne bilance omogočajo vpogled v mehanizem napajanja vodonosnika. Poleg tega je določitev količine vode, ki se infiltrira skozi talni profil, nujna za napoved prenosa onesnaževal znotraj nezasičene cone (Meissner in sod., 2007).

$\mathrm{Na}$ območju vodonosnika Ljubljanskega polja so narejene številne študije o kakovosti in količinskemu stanju ter dinamiki podzemne vode. Peščeno-prodni vodonosnik se v glavnem napaja iz dveh komponent, in sicer iz reke Save, ki se infiltrira skozi zelo prepustne sedimente ter iz padavin, ki se infiltrirajo do vodonosnih plasti na Ljubljanskemu polju (Breznik, 1969; Urbanc in Jamnik, 1998, Vrzel in sod., 2018). Deleža omenjenih komponent sta v različnih delih vodonosnika dokaj različna (Jamnik in Urbanc, 2000). Kakovost podzemne vode Ljubljanskega polja so obravnavali Urbanc in Jamnik (2007) ter Bračič Železnik in sod., (2011). Čeprav so bile opravljene številne raziskave, ki so se ukvarjale z ugotavljanjem hidrogeoloških lastnosti vodonosnika Ljubljanskega polja (Šram in sod., 2012), ostaja napajanje vodonosnika še vedno relativno neraziskano. Predvsem je težko opredeliti infiltracijo padavin in tok vode skozi heterogeno nezasičeno cono vodonosnika zaradi spremenljivih fizikalnih in kemijskih lastnosti nezasičene cone (Vižintin in sod., 2009; McGrath in sod., 2015). V študiji Zupanc in sod., 2012, je bila narejena ocena vodne bilance zgornje nezasičene cone, a je bilo to narejeno za sušno obdobje, zato smo procese $\mathrm{v}$ nezasičeni coni in vodno bilanco ovrednotili za hidrološko leto $\mathrm{z}$ več padavinami.

\section{METODE DELA}

Lizimeterska postaja v Klečah (Slika 1 in 2) je bila zgrajena $\mathrm{v}$ osemdesetih letih prejšnjega stoletja $\mathrm{z}$ namenom ocenjevanje vodne bilance lizimetra (Brilly in Gorišek, 1985). Takrat sta bila narejena dva lizimetra $\mathrm{v}$ betonskem jašku z možnostjo spremljanja iztoka $\mathrm{v}$ kontrolnem jašku. Leta 2010 je bil na mestu starega lizimetra vgrajen monolitni tehtalni lizimeter (von Unold in Fank, 2008), katerega površina je $1 \mathrm{~m}^{2}$, globina pa $2 \mathrm{~m}$. Lizimetri so naprave, ki se uporabljajo za določitev posameznih členov vodne bilance (dejanska evapo- transpiracija, napajanje vodonosnika) in raziskave dinamike toka vode in prenosa snovi v nezasičeni coni na številnih področjih, tako $\mathrm{v}$ agronomiji, hidrologiji, meteorologiji in v okoljskih znanostih (Pintar, 2003; Bračič Železnik in sod., 2011; Meissner in sod., 2010; Kohfahl in sod., 2019; Klammler in Fank, 2014; Schrader in sod. 2013). Znotraj monolitnega lizimetra $v$ Klečah so na globinah $50 \mathrm{~cm}, 100 \mathrm{~cm}$ in $150 \mathrm{~cm}$ nameščeni senzorji za meritve vodnega potenciala (tenziometri) in količine vode ter vzorčevalniki vode. Na globini $190 \mathrm{~cm}$ sta nameščena dva tenziometra (en znotraj lizimetra in en zunaj) za uravnavanje robnih pogojev na dnu lizimetra. Meritve omogočajo izračun vodne bilance lizimetra (Zupanc in sod., 2012).

Tehtalni sistem ima natančnost do $30 \mathrm{~g}$ in omogoča neprekinjeno spremljanje količine vode znotraj lizimetra. Zaradi velike občutljivosti lizimeter zazna že zelo majhne spremembe $v$ teži, zato je treba pri vrednotenju niza podatkov upoštevati vse možne napake zaradi zunanjih vplivov: košnja trave, hoja živali, rast trave itd. Rast vegetacije nismo ocenjevali, ker smo predvidevali konstantno višino trave. za natančnejše ovrednotenje bi potrebovali dnevnik košenj. Zaradi tega je zelo pomembno, da se vse aktivnosti in morebitne napake na lizimetru skrbno beležijo (čas košnje, odvzema vzorcev in/ali podatkov, odbobje brez baterije, obdobje nedelovanja posamezne sonde ipd.).

Členi osnovne vodne bilance lizimetra so padavine $(P)$, evapotranspiracija $(E T)$, iztok $(O)$ in sprememba zaloge vode $\mathrm{v}$ tleh $(\Delta S)$, ki so vsi podani $\mathrm{v} \mathrm{mm}$ (enačba (1)). Iztok $(O)$ je masa vode, ki izteče iz lizimetra med dvema časovnima korakoma, t.j. med dvema meritvama mase vode, odtekle iz lizimetra. Na zalogo vode $\mathrm{v}$ lizimetru $(S)$ vpliva razmerje med posameznimi členi osnovne vodne bilance. $V$ članku obravnavamo spremembo zaloge vode $\mathrm{v}$ tleh, ker celokupne zaloge vode nismo ocenjevali.

$$
P-E T-O-\triangle S=0
$$

$\mathrm{K}$ zmanjševanju mase lizimetra prispevata iztok in evapotranspiracija. Slednja je bila izračunana kot razlika spremembe mase lizimetra in iztoka $\mathrm{v}$ dveh časovnih korakih:

$$
\left(W_{i}-W_{i+1}\right)-\left(O_{i+1}-O_{i}\right)=E T_{a}
$$

kjer so masa lizimetra $(\mathrm{kg})$, masa posode za iztok (kg), dejanska evapotranspiracija $(\mathrm{mm})$ ter časovni korak. Vsi parametri morajo biti merjeni v enakem časovnem koraku. Na lizimeterski postaji Kleče sta iztok in masa lizimetra merjena $\mathrm{v}$ 1-minutnem intervalu. Spremembo mase lizimetra $W$ smo izračunali kot 
razliko med začetno vrednostjo, preden ta začne strmo upadati, in končno vrednostjo, ko se proces evapotranspiracije prekine.

Količino iztoka $O$ smo izračunali kot razliko med končno in začetno vrednostjo časovnega koraka. Začetna vrednost je definirana kot začetek naraščanja, medtem ko je končna vrednost takrat, ko spremembe iztoka ni moč zaznati. Količino iztoka v enem dnevu (od 0:00 do 24:00) smo izračunali po naslednji enačbi:

$$
\left(O_{i+1}-O_{i}\right)+\left(O_{i}-O_{i-1}\right)+\ldots=O_{0 h-24}
$$

Pozitivne vrednosti iztoka iz lizimetra prispevajo k napajanju podzemne vode. Negativen iztok pa predstavlja pritok vode nazaj v lizimeter, ki se sproži v sušnem obdobju na podlagi meritev dveh tenziometrov, ki na globini $190 \mathrm{~cm}$ (dno lizimetra) znotraj in zunaj lizimetra uravnavata robne pogoje (Zupanc in sod., 2012).

$\mathrm{S}$ pomočjo meritev mase lizimetra smo določili tudi količino padavin $\left(P_{\text {lys }}\right)$. Padavinski dogodek smo določili iz grafa mase lizimetra $W$ v odvisnosti od časa ter nato izračunali iz spremembe mase lizimetra $\Delta W$ med zadnjo vrednostjo $W$, preden se je začela dvigati in najvišjo vrednostjo $W$, preden je ta začela upadati (posledica ET ali O). Razlika v masi predstavlja količino padavin v Klečah, izračunano po enačbi:

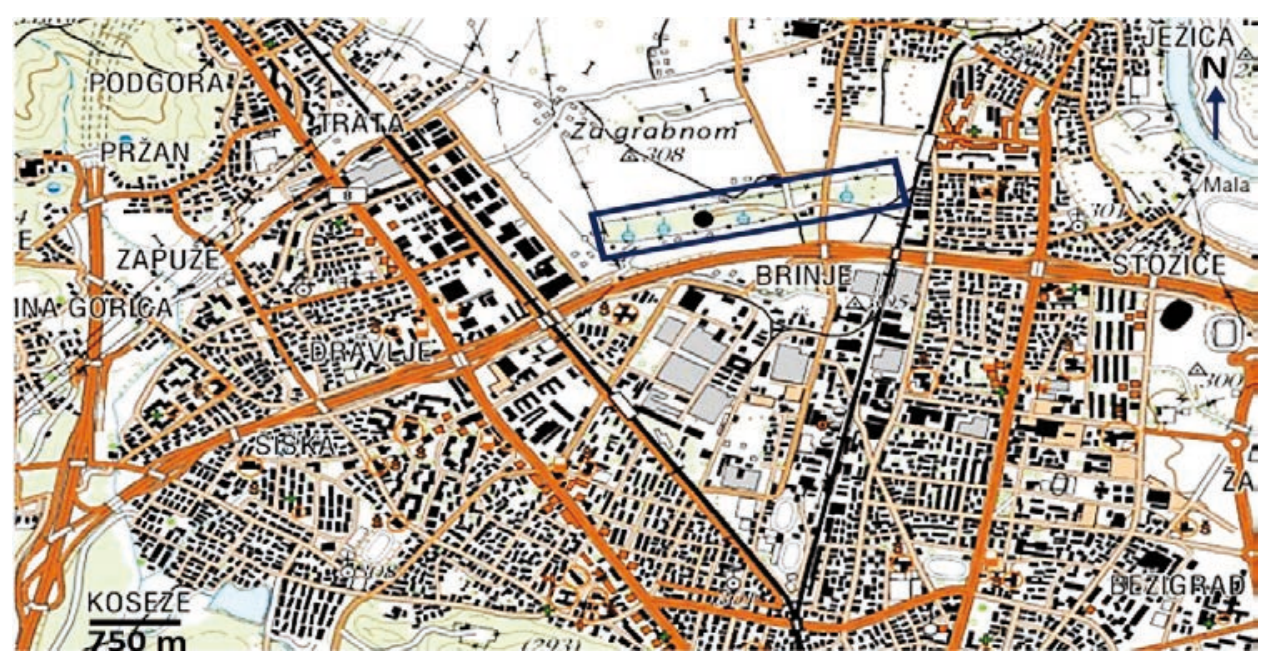

Slika 1: Geografska umestitev lizimetra (črn krog) z vodarno Kleče (pravokotnik; GURS, 2017)

Figure 1: Geographical position of the lysimeter (black circle) within the well field Kleče (rectangle; GURS, 2017)

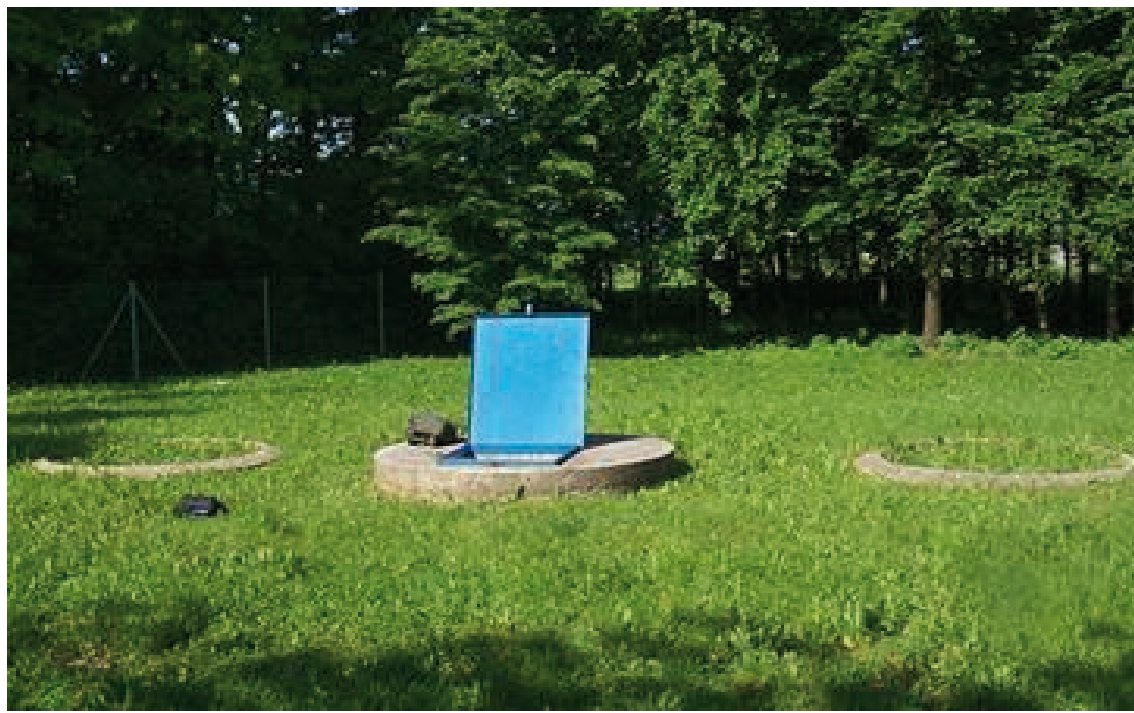

Slika 2: Lizimeterska postaja v Klečah

Figure 2: Kleče Lysimeter station 


$$
P_{l y s}=\left(P_{i+1}-P_{i}\right)
$$

Izračunane vrednosti $E T_{\mathrm{a}}, \mathrm{O}$ in $P_{\text {lys }}$ omogočajo izračun spremembo zaloge vode $\Delta S$ za časovni niz 24 ur (od 0:00 do 24:00) po enačbi:

$$
\Delta S=P-E T-O
$$

Dejansko evapotranspiracijo, ki smo jo določili iz meritev na lizimetru Kleče, smo primerjali z referenčno evapotranspiracijo $\left(E T_{0}\right)$, ki je bila izračunana po Penman-Monteithovi metodi na osnovi meritev na meteorološki postaji Ljubljana-Bežigrad (ARSO, 2018; Allen in sod., 1998).

$\mathrm{V}$ prispevku podrobno obravnavamo razmere na lizimetrski postaji v Klečah za mesec junij 2014, ko je bilo suho, vroče obdobje, in mesec oktober 2014, ko je bilo mokro obdobje. Prav tako smo izračunali mesečno vodno bilanco za eno hidrološko leto (obdobje marec 2014 - februar 2015).

\section{REZULTATI Z DISKUSIJO}

Za obravnavano hidrološko leto predstavljamo dve ekstremni vremenski obdobji (slika 3), v času katerih je bila izmerjena masa lizimetra najmanjša (junij) in največja (oktober) ter mesečno vodno bilanco.

$\mathrm{V}$ juniju je bilo suho in vroče obdobje $\mathrm{z}$ visoko temperaturo zraka $\left(\mathrm{T}_{\max }=35^{\circ} \mathrm{C}\right)$ in majhno količino padavin, zato so bile razmere $\mathrm{v}$ tleh sušne. $\mathrm{V}$ mesecu oktobru je bil ekstremni padavinski dogodek z obilno količino padavin, temperature pa so bile nizke, kar je ustvarilo pogoje za doseg največje mase lizimetra (mokro obdobje).

\subsection{VODNA BILANCA ZA MESEC JUNIJ 2014}

$\mathrm{Na}$ osnovi spremembe mase lizimetra $W$ (slika 4) smo določili 15 padavinskih dogodkov, od tega dva znatna (24. 6. in 25. 6.) in tri manjše (12. 6., 13. 6. in 29. 6.). Skupna količina padavin za mesec junij 2014 je bila $87,7 \mathrm{~mm}$ (preglednica 1 ).

Masa lizimetra $W$ (Slika 4) je v začetku meseca junija padla $\mathrm{z}$ največje vrednosti $4102,1 \mathrm{~kg}$ (1. 6. ob 0:00) na 4052,0 kg (12. 6. ob 14:30), kar pomeni, da se je zaloga vode v lizimetru $S$ v tem obdobju zmanjšala $(\Delta S=50,1 \mathrm{~mm})$. Količina vode, ki je iztekla $(O)$, je bila $0,1 \mathrm{~mm}$.

Padavinski dogodek 12. 6. se je začel ob 14:30 ( $W$ $=4052,0 \mathrm{~kg})$ in trajal do 15:22 ( $W=4060,7 \mathrm{~kg})$ ter se nato po krajšemu premoru nadaljeval do $20: 31$ ( $W=$ $4062,6 \mathrm{~kg})$, kar je povečalo zalogo vode $\mathrm{v}$ tleh $(\Delta S=$ $10,6 \mathrm{~mm})$ in količino iztoka $O(0,1 \mathrm{~mm})$. Po padavinskemu dogodku 12. 6. se je masa lizimetra $W$ zmanjšala in je 23. 6. ob 20:54 dosegla najmanjšo vrednost 4029,4 kg v mesecu juniju (Slika 4). Zmanjšali sta se zaloga vode v tleh $S(33,2 \mathrm{~mm})$ in iztok $O(0,2 \mathrm{~mm})$.

Med 23. 6. in 25. 6. sta bila zabeležena dva padavinska dogodka, ki sta doprinesla glavnino padavin v juniju (57,1 mm). Prvi se je začel 23. 6. ob 21:40 $(W=4029,4 \mathrm{~kg})$ in se nadaljeval naslednjega dne do 8:03 ( $W=4052,2 \mathrm{~kg}$ ). Padavine so se po krajši preki-

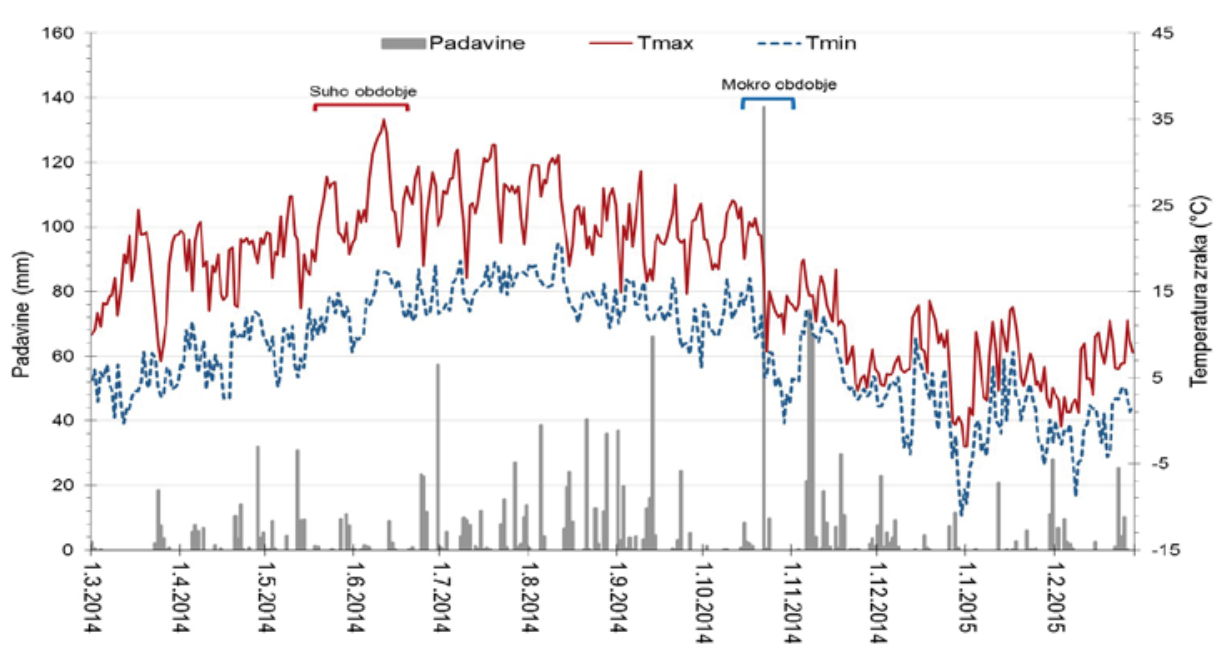

Slika 3: Dnevna količina padavin $(\mathrm{mm})$ ter dnevna maksimalna in minimalna temperatura zraka $\left({ }^{\circ} \mathrm{C}\right)$ za meteorloško postajo Ljubljana-Bežigrad v obdobju med marcem 2014 in februarjem 2015 z označenim suhim in mokrim obdobjem (ARSO, 2018) Figure 3: Daily rainfall $(\mathrm{mm})$ and daily maximum and minimum air temperature $\left({ }^{\circ} \mathrm{C}\right)$ for the meteorological station Ljubljana-Bežigrad in the period from March 2014 to February 2015 with marked dry and wet season (ARSO, 2018) 


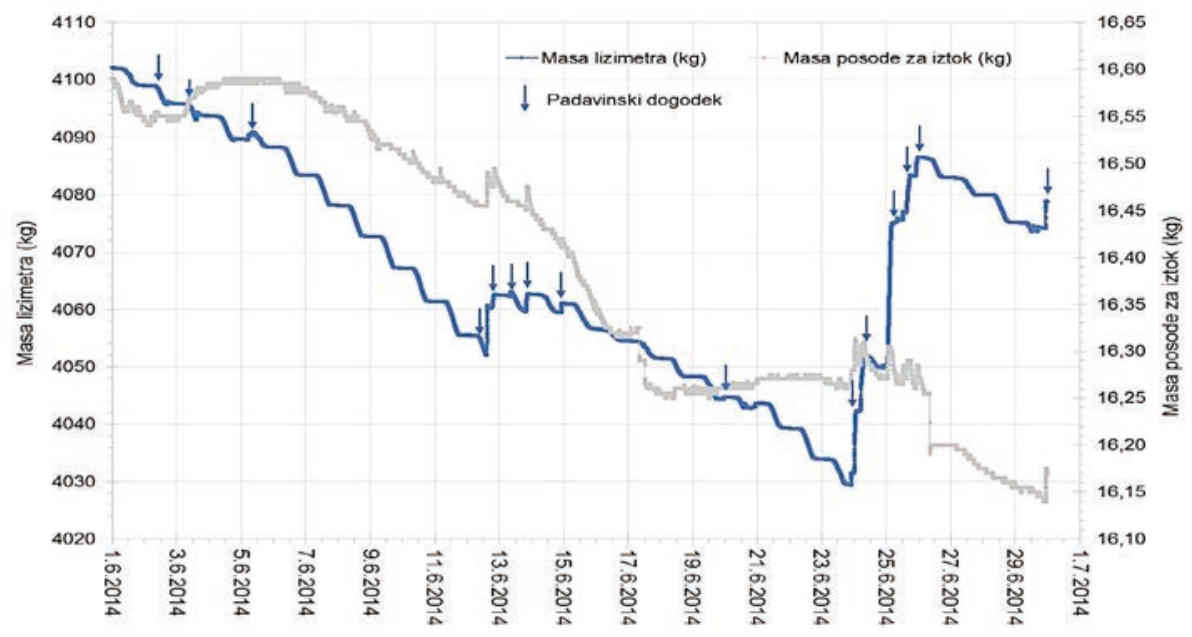

Slika 4: Masa lizimetra in posode za iztok (kg) ter zaznani padavinski dogodki v juniju 2014 (Šerjak, 2019)

Figure 4: Mass of lysimeter and outflow container $(\mathrm{kg})$ and detected rainfall events in June 2014 (Šerjak, 2019)

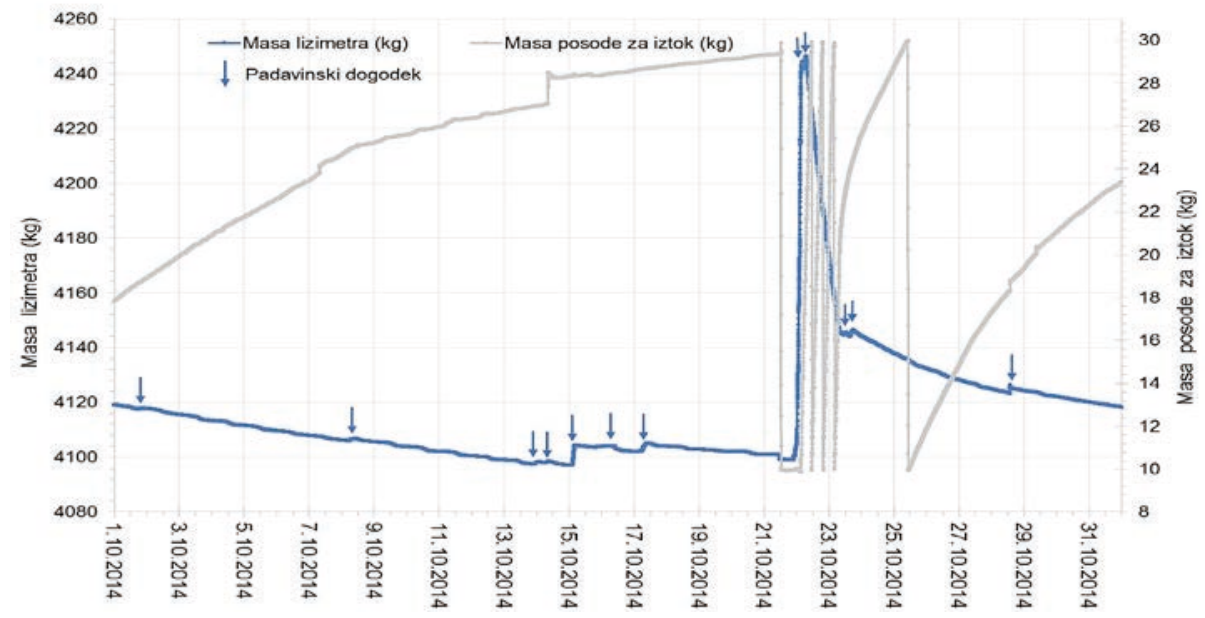

Slika 5: Masa lizimetra in posode za iztok (v kg) ter zaznani padavinski dogodki v oktobru 2014 (Šerjak, 2019)

Figure 5: Mass of lysimeter and outflow container $(\mathrm{kg})$ and detected rainfall events in October 2014 (Šerjak, 2019)

nitvi nadaljevale $\mathrm{v}$ drugi padavinski dogodek, ki je se je začel 24. 6. ob 21:35 ( $W=4050,1 \mathrm{~kg})$ in končal 25. 6 . ob 23:41 ( $W=4086,5 \mathrm{~kg})$. Le-te so povzročile, da sta se povečala zaloga vode $\mathrm{v}$ tleh $(\Delta S=57,1 \mathrm{~mm})$ in iztok iz lizimetra $O(0,1 \mathrm{~mm})$.

Na sliki lahko opazimo nagel upad mase iztoka 26. 6. ob 8:20, ki se je zgodil zaradi pobiranja vzorcev, zato se ta podatek ni upošteval $v$ izračunu vodne bilance.

\subsection{VODNA BILANCA ZA OKTOBER 2014}

$\mathrm{Na}$ osnovi spremembe mase lizimetra $W$ (Slika 5) smo določili 12 padavinskih dogodkov, od tega enega večjega (22. 10.) in tri manjše (15. 10., 17. 10. in 21.
10.). Skupna količina padavin za mesec oktober je bila 169,7 mm (preglednica 1).

V obdobju od 1. 10. do 21. 10. ni bilo izrazitih padavinskih dogodkov, ki bi opazno vplivali na porast mase lizimetra. Zabeleženi so bili kratkotrajni padavinski dogodki 1. 10., 8. 10. ter med 13.10. in 17. 10. Masa lizimetra $W$ je bila med $4119,1 \mathrm{~kg}$ (1. 10. ob 0:00) in $4099,0 \mathrm{~kg}$ (21. 10. ob 20:52), kar pomeni, da se je zaloga vode v lizimetru zmanjšala $(\Delta S=20,1 \mathrm{~mm})$. Masa lizimetra $W$ je 15. 10. ob 0:46 dosegla najmanjšo vrednost $(4097,2 \mathrm{~kg})$ za mesec oktober (slika 5). V obdobju od 1. 10. do 21. 10. je količina iztoka narastla $(12,0 \mathrm{~mm})$, čeprav v tem obdobju ni bilo zabeleženih večjih padavinskih dogodkov, vendar je prihajalo do izcejanja vode 


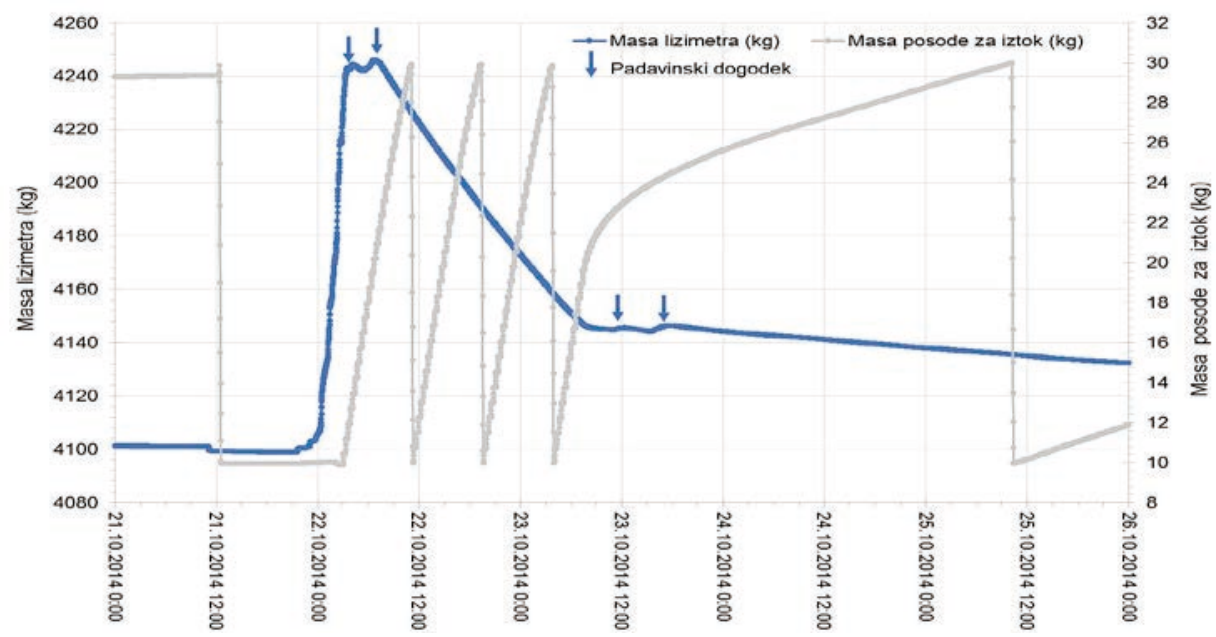

Slika 6: Masa lizimetra in posode za iztok (v kg) ter zaznani padavinski dogodki v obdobju med 21. 10. in 26. 10. 2014 (Šerjak, 2019)

Figure 6: Figure 6: Mass of lysimeter and outflow container $(\mathrm{kg})$ and detected rainfall events in the period from 21.10 . to 26. 10. 2014 (Šerjak, 2019)

iz lizimetra, saj so bila tla blizu zasičenja zaradi padavin, ki so bile v mesecu septembru.

$\mathrm{V}$ mesecu oktobru se je zgodil ekstremni padavinski dogodek (143,5 mm; slika 5 in 6). Ekstremni kratkotrajni padavinski dogodek $\mathrm{z}$ veliko intenziteto padavin je trajal od 21. do 22. 10. (slika 6). Padavine so se začele ob 20:52 ( $W=4099,0 \mathrm{~kg})$ ter trajale do 6:52 naslednjega dne ( $W=4246,4 \mathrm{~kg})$. Največja intenziteta naliva $\left(34,7 \mathrm{~mm} \cdot \mathrm{h}^{-1}\right)$ je bila 22. 10., saj je od 0:00 do 4:05 padlo $139,0 \mathrm{~mm}$ padavin. Zaradi obilnih padavin sta se povečali zaloga vode $\mathrm{v}$ tleh $\Delta S(147,4 \mathrm{~mm})$ in iztok vode iz lizimetra $O(10,4 \mathrm{~mm})$. Posoda za iztok ima omejitev $30 \mathrm{~kg}$, zato se je v tem obdobju večkrat spraznila, kar se odraža kot žagasta krivulja iztoka na slikah 5 in 6 .

\subsection{MESEČNA VODNA BILANCA V OBDOBJU MED MARCEM 2014 IN FEBRUARJEM 2015}

Izbrano hidrološko leto je bilo bogato s padavinami, ki so pozitivno vplivale na vodno bilanco lizimetra (Preglednica 1) in na napajanje vodonosnika. Na območju Kleč padavinska postaja ne deluje več, zato smo rezultate izračuna padavin za lizimeter Kleče primerjali s padavinami na meteorološki postaji Ljubljana-Bežigrad ( $\mathrm{P}_{\mathrm{ARSO}}$; ARSO, 2018), za katero so podane vsote dnevnih padavin od $7 \mathrm{~h}$ do $7 \mathrm{~h}$. V posameznih mesecih je količina padavin presegla dolgoletno povprečje ARSO (2019b). Izjemno vodnati mesic so bili avgust (178,7 mm; Preglednica 1), september (172,8 mm), oktober $(169,7 \mathrm{~mm})$ in november $(192,3 \mathrm{~mm})$. V oktobru (22. 10.; Slika 6) je bil ekstremni padavinski dogodek
(143,5 mm), ki je presegel 100-letno povratno dobo (ARSO, 2019b). Količina padavin, izračunanih iz meritev v lizimetru, odstopa od meritev na meteorološki postaji Ljubljana-Bežigrad (ARSO, 2018). Odstopanje je najmanjše $\mathrm{v}$ oktobru in od decembra do marca; medtem ko je največje odstopanje $\mathrm{v}$ mesecu novembru. $\mathrm{Na}$ količino padavin vplivajo številni dejavniki (npr. veter in vegetacija - gozd), zato so lahko razlike tudi na manjšem območju. Zaradi tega je potrebno vzpostaviti padavinsko postajo na lizimetru Kleče za primerjavo izračunih padavin iz podatkov lizimetra . Skupna količina padavin v obravnavanem obdobju je bila 1369,4 mm (Preglednica 1).

$\mathrm{V}$ obravnavanem obdobju je bila največja evapotranspiracija (Preglednica 1) v mesecu maju (103,9 mm), juniju (106,9 mm), juliju $(94,7 \mathrm{~mm})$ in avgustu (106,2 mm). Iz lizimetra je v izbranem hidrološkem letu izhlapelo $646,5 \mathrm{~mm}$ vode. V Preglednici 1 so podani rezultati izračunane mesečne dejanske evapotranspiracije $\left(E T_{\mathrm{a}}\right)$ na podlagi meritev v lizimetru Kleče ter izračunane referenčne evapotranspiracije za postajo Ljubljana-Bežigrad (ET ; ARSO, 2018). Vrednosti $E T_{a}$ in $E T_{0}$ se razlikujejo, kar so ugotovili že Zupanc s sod. (2012). $E T_{0}$ je izračunana po Penman-Monteithvi enačbi za aktivno rastočo travo, ki popolnoma prekriva tla in je zadostno preskrbljena $z$ vodo (ARSO, 2018; Allen et al., 2006, 2011) in gre za potencialno ET. Travnata površina na lizimetru ni namakana, zato ni vedno na voljo optimalna količina vode in je dejanska evapotranspiracija lahko manjša od referenčne. Poleg tega se meteorološke razmere delno razlikujejo zaradi različnih lokacij (Kleče / Bežigrad). Na vrednosti izračunane eva- 
potranspiracije lahko vplivajo tudi intenzivni nalivi po daljšemu sušnemu obdobju, ko je možen tok vode čez lizimeter (hipni preliv preko silikonske zaščite vmesnega prostora med lizimetrom in okoliškimi tlemi), kar je na grafu vidno kot nenadni strmi upad mase lizimetra in so zato posledično večje vrednosti ETa. Nekatere vrednosti dnevne $E T_{a}$ pa so bile premajhne zaradi padavin, ki so se pojavile tekom dneva in so prekrile evapotranspiracijo na grafu mase lizimetra.

V prvi polovici obravnavanega obdobja (od marca do julija) se je količina iztoka iz lizimetra manjšala (pomanjkanje padavin in/ali povečana evapotranspiracija) in dosegla negativne vrednosti v maju $(-0,5 \mathrm{~mm})$, juniju $(-0,4 \mathrm{~mm})$ in juliju $(-1,1 \mathrm{~mm})(O$; Preglednica 1). Negativne vrednosti se pojavljajo v izredno sušnih razmerah, ko se v lizimetru zaradi uravnavanja robnih pogojev črpa voda iz posode za iztok nazaj v lizimeter. V tem sušnem obdobju se vodonosnik ni napajal. Prihajalo je do kapilarnega dviga iz nižjih plasti v višje. Kapilarni dvig vode je v primerjavi s tokom vode iz vrhnjih plasti (iztok iz lizimetra) navzdol zelo majhen.

$\mathrm{V}$ drugi polovici izjemno namočenega hidrološkega leta se je količina iztoka iz lizimetra povečala in dosegla največje vrednosti v mesecu oktobru $(105,3 \mathrm{~mm})$ in novembru $(159,7 \mathrm{~mm})$ (Preglednica 1). Pozitivna sprememba zaloge vode v lizimetru pomeni, da so bili v obravnavanem času pritoki preko padavin večji kot izgube (ET in iztok) iz lizimetra (Bračič Železnik in sod., 2011; Zupanc in sod., 2012).V tem obdobju je bila količina padavin velika, bilo je tudi nekaj intenzivnih nalivov ter ekstremni padavinski dogodek (22.10.). V tem obdobju je količina padavin presegla dolgoletno povprečje za meteorološko postajo Ljubljana-Bežigrad (v avgustu, septembru, oktobru, novembru in januarju). Nadpovprečne količine padavin so se infiltrirale skozi nezasičeno cono in napajale vodonosnik. Ekstremni padavinski dogodek in intenzivni nalivi so $\mathrm{v}$ jesenskemu obdobju (september, oktober in november) skupno doprinesli 534,8 $\mathrm{mm}$ padavin (Preglednica 1). V mesecu septembru, oktobru in novembru je bilo skupno $350,0 \mathrm{~mm}$ iztoka, kar pomeni, da je $\mathrm{v}$ teh treh mesecih $65 \%$ mesečnih padavin izteklo iz lizimetra oz. napajalo podzemno vodo. $V$ jesenskemu obdobju se je vodonosnik znatno napajal z infiltracijo padavin, kar je ugodno vplivalo na obnavljanje podzemne vode. To je skladno z ugotovitvami Zupanc s sod. (2012), ki so potrdili, da večji padavinski dogodki ali daljša padavinska obdobja doprinesejo $\mathrm{k}$ bogatenju podzemne vode tudi $\mathrm{v}$ manj mokrem obdobju. Skupna količina iztoka iz lizi-

Preglednica 1: Parametri mesečne vodne bilance za obdobje marec 2014 - februar 2015: količina iztoka iz lizimetra O(0 h-24h), sprememba zaloge vode v lizimetru $\Delta$ S, padavine na postaji Ljubljana-Bežigrad PARSO (7 h-7 h) (ARSO, 2018), padavine (meritve v lizimetru; Plys (0 h-24 h), ET0 (Ljubljana-Bežigrad; ARSO, 2018) in ETa (meritve v lizimetru) (Šerjak, 2019)

Table 1: Monthly water balance parameters for the period March 2014 - February 2015: lysimeter outflow amount O(0 h-24 h), change in soil water storage in lysimeter $\Delta \mathrm{S}$, rainfall for the meteorological station Ljubljana-Bežigrad PARSO (7 h-7 h) (ARSO, 2018), rainfall (lysimeter measurements; Plys (0 h-24 h), ET0 (Ljubljana-Bežigrad; ARSO, 2018) and ETa (lysimeter measurements) (Šerjak, 2019)

\begin{tabular}{|c|c|c|c|c|c|c|}
\hline Mesec & $\begin{array}{l}O_{(0 \mathrm{~h}-24 \mathrm{~h})} \\
(\mathrm{mm})\end{array}$ & $\begin{array}{l}\Delta S \\
(\mathrm{~mm})\end{array}$ & $\begin{array}{l}P_{\text {ARSO (7 h-7 h) }} \\
(\mathrm{mm})\end{array}$ & $\begin{array}{l}P_{\text {lys }(0 \mathrm{~h}-24 \mathrm{~h})} \\
(\mathrm{mm})\end{array}$ & $\begin{array}{l}E T_{0(\text { ARSO })} \\
(\mathrm{mm})\end{array}$ & $\begin{array}{l}E T_{a} \\
(\mathrm{~mm})\end{array}$ \\
\hline Marec & 15,4 & $-17,0$ & 35,4 & 36,3 & 64,6 & 37,9 \\
\hline April & 4,1 & 24,9 & 97,5 & 83,1 & 77,5 & 54,0 \\
\hline Maj & $-0,5$ & 5,8 & 94,0 & 109,1 & 117,2 & 103,9 \\
\hline Junij & $-0,4$ & $-18,8$ & 74,0 & 87,7 & 128,8 & 106,9 \\
\hline Julij & $-1,1$ & 21,5 & 130,3 & 115,1 & 119,6 & 94,7 \\
\hline Avgust* & 6,6 & 65,9 & 205,0 & 178,7 & 99,1 & 106,2 \\
\hline September & 85,0 & 32,6 & 203,6 & 172,8 & 58,6 & 55,1 \\
\hline Oktober & 105,3 & 25,5 & 163,4 & 169,7 & 43,4 & 38,9 \\
\hline November & 159,7 & 18,3 & 248,6 & 192,3 & 15,2 & 14,3 \\
\hline December & 47,8 & 21,6 & 77,9 & 77,4 & 11,9 & 8,0 \\
\hline Januar & 28,9 & 35,2 & 69,7 & 76,0 & 13,4 & 11,9 \\
\hline Februar & 49,8 & 6,8 & 64,3 & 71,2 & 15,9 & 14,7 \\
\hline SKUPAJ & 500,6 & 222,3 & 1463,7 & 1369,4 & 765,2 & 646,5 \\
\hline
\end{tabular}

* izračuni so podvrženi tehničnim napakam, ki so se pojavljala pri beleženju podatkov (npr. nedelovanje sond zaradi pomanjkanja energije). V mesecu avgustu sta iz izračunov izključena parametra $\mathrm{O}$ in $\Delta \mathrm{S}$ za 26. 8., 27. 8. in 28. 8. Iz izračunov so izključeni tudi 30. 6., 31. 8. in 28. 2. 
metra $\mathrm{v}$ hidrološkem letu je bila pozitivna in je znašala 500,6 mm (Preglednica 1).

Spremembo zaloge vode $\mathrm{v}$ lizimetru predstavlja razlika med količino infiltrirane vode (padavine ali črpanje vode iz posode za iztok v lizimeter) ter $E T_{a}$ in iztokom vode iz lizimetra (izguba vode; Preglednica 1). Sprememba zaloge vode $\mathrm{v}$ lizimetru $(\Delta S$; preglednica 1) je bila pozitivna $\mathrm{v}$ mesecu aprilu $(24,9 \mathrm{~mm})$, maju $(5,8 \mathrm{~mm})$, juliju $(21,5 \mathrm{~mm})$, avgustu $(65,9 \mathrm{~mm})$, septembru $(32,6 \mathrm{~mm})$, oktobru $(25,5 \mathrm{~mm})$, novembru $(18,3 \mathrm{~mm})$, decembru $(21,6 \mathrm{~mm})$, januarju $(35,2 \mathrm{~mm})$ in februarju $(6,8 \mathrm{~mm})$. Navedeni meseci so bili bogati $\mathrm{s}$ padavinskimi dogodki, ki so ugodno vplivali na zaloge vode v lizimetru. Negativne vrednosti so bile v mesecu marcu $(-17,0 \mathrm{~mm})$ in juniju $(-18,8 \mathrm{~mm})$, kar sovpada s padavinskim primanjkljajem (ARSO, 2019a). Skupna vrednost spremembe zaloge vode $\mathrm{v}$ lizimetru $\mathrm{v}$ obravnavanemu obdobju je bila pozitivna $(222,3 \mathrm{~mm})$, kar pomeni, da so bili pritoki vode večji kakor izgube iz lizimetra.

\section{ZAKLJUČKI}

V prispevku smo obravnavali vodno bilanco lizimetra na območju vodarne Kleče $\mathrm{v}$ Ljubljani $\mathrm{z}$ vidika napajanja vodonosnika Ljubljanskega polja. Izračuni so bili narejeni le za eno hidrološko leto, zato rezultati ne predstavljajo dolgoletnega povprečja, temveč dinamiko procesov v izbranem hidrološkem letu (marec 2014 februar 2015).

V obravnavanem obdobju so bile izrazite padavine ter ekstremni padavinski dogodek, ki se je zgodil 22. oktobra 2014. V celotnem obravnavanem obdobju je padlo $1369,4 \mathrm{~mm}$ padavin.

Z lizimetrom v Klečah smo določili dejansko evapotranspiracijo, ki je znašala $646,5 \mathrm{~mm}$ (oz. 47 \% padavin). Sprememba zaloge vode $\mathrm{v}$ lizimetru v izbranem hidrološkem letu je bila pozitivna $(222,3 \mathrm{~mm}$ oz. $16 \%$ padavin).

Iztok iz lizimetra je znašal 500,6 mm (oz. 37 \% padavin). Iztok iz lizimetra pove, kolikšno je napajanje vodonosnika iz padavin $\mathrm{v}$ izbranem hidrološkem letu. $\mathrm{V}$ prvi polovici obravnavanega obdobja (od marca do avgusta 2014) so bile razmere za napajanje vodonosnika $\mathrm{z}$ infiltracijo padavin manj ugodne kakor $\mathrm{v}$ drugi polovici hidrološkega leta (od septembra 2014 do februarja 2015). Napajanje vodonosnika $\mathrm{z}$ infiltracijo padavin je bilo največje $\mathrm{v}$ septembru, oktobru in novembru.

Padavine so prispevale tako $\mathrm{k}$ uskladiščenju infiltrirane vode $\mathrm{v}$ nezasičeni coni, kakor tudi k napajanju vodonosnika. Zaradi velike dinamike vseh členov vo- dne bilance je zelo pomemben izračun mesečne vodne bilance.

Lizimeter omogoča izračun parametrov vodne bilance za nezasičeno cono, ki jih sicer težko ovrednotimo, a so pomembni za celostne študije napajanja vodonosnika in modeliranja toka podzemne vode.

\section{ZAHVALA}

Zahvaljujemo se mag. Branki Bračič Železnik za posredovanje in uporabo podatkov. Raziskave na lizimetru Kleče so bile opravljene s finančno podporo Evropskega sklada za regionalni razvoj (European Regional Development Fund) v okviru projektov CC-WaterS (No. SEE/D/0143/2.1/X) in CC-WARE (No. SEE/A/022/2.1/X), oba programu transnacionalnega sodelovanja Jugovzhodna Evropa.

\section{LITERATURA}

Allen R. G., Pereira L. S., Raes D., Smith M. (1998). Crop evapotranspiration - Guidelines for Computing Crop Water Requirements. Rome: Food and Agriculture Organization of the United Nations.

Allen, R.G., Pruitt, W.O., Wright, J.L., Howell, T.A., Ventura, F., Snyder R. (2006). A recommendation on standardized surface resisdence for hourly calculation of reference $\mathrm{ET}_{0}$ by the FAO56 Penman-Monteith method. Agricultural Water Management, 81, 1-22. https://doi.org/10.1016/j. agwat.2005.03.007

Allen R.G., Pereira L.S., Howell T.A., Jensen M.E. (2011). Evapotranspiration information reporting: I. Factors governing measurement Accuracy: review. Agricultural Water Management, 98, 899-920. https://doi.org/10.1016/j.agwat.2010.12.015

ARSO. (2018). Pregled agrometeoroloških spremenljivk: Tabela (dnevni podatki v mesecu) za meteorološko postajo Ljubljana Bežigrad. Pridobljeno s http://meteo.arso.gov.si/ met/sl/agromet/data/month/

ARSO. (2019a). Meteorološka postaja Ljubljana Bežigrad: Povratne dobe za ekstremne padavine (novejša različica). Pridobljeno s http://meteo.arso.gov.si/uploads/probase/ www/climate/table/sl/by_variable/return-periods/Ljubljana\%20Bezigrad.pdf

ARSO. (2019b). Mesečna povprečja višine padavin. Pridobljeno s http://meteo.arso.gov.si/met/sl/climate/maps/monthlymean-precipitation-maps/

Bračič Železnik B., Zupanc V., Pintar M. (2011). Naravno ozadje nitratov - meritve na lizimetru Kleče na Ljubljanskem polju. V 22. Mišičev vodarski dan: zbornik referatov (str. 120-125). Maribor : Vodnogospodarski biro Maribor.

Breznik M. (1969). Groundwater of the Ljubljana polje and possibilities of increasing its exploitation. Geologija, 12, 165-184.

Brilly M., Gorišek M. (1985). Matematični model podtalnice 
Ljubljanskega polja : II. Faza raziskave podtalne vode na Ljubljanskem Barju, Ljubljana : FAGG, Laboratorij za mehaniko tekočin.

GURS. (2017). Državna pregledna karta merila $1: 250000$ [online]. Pridobljeno s https://www.e-prostor.gov.si/ zbirke-prostorskih-podatkov/topografski-in-kartografski-podatki/topografski-podatki-in-karte/drzavnepregledne-karte/\#tab2-1044\%3E.

Jamnik B., Urbanc J. (2000). Izvor in kakovost podzemne vode Ljubljanskega polja = Origin and guality of groundwater from Ljubljansko polje. RMZ Materiali in geookolje, 47(2), 168-178.

Klammler G., Fank, J. (2014). Determining water and nitrogen balances for beneficial management practices using lysimeters at Wagna test site (Austria). Science of The Total Environment, 499, 448-462. https://doi.org/10.1016/j.scitotenv.2014.06.009

Kohfahl, C., Molano-Leno, L., Martinez, G., Vanderlinden, K., Guardiola-Albert, C., Moreno, L. (2019). Determining groundwater recharge and vapor flow in dune sediments using a weighable precision meteo lysimeter. Science of the Total Environment, 656, 550-557. https:/doi. org/10.1016/j.scitotenv.2018.11.415

McGrath S., Ratej J., Jovičić V., Čenčur Curk B. (2015). Hydraulic characteristics of alluvial gravels for different particle sizes across a wide range of pressure heads. Vadose zone Journal, 14(3), 1539-1663. https://doi.org/10.2136/ vzj2014.08.0112

Meissner R., Seeger J., Rupp H., Seyfarth M., Borg H. (2007). Measurement of dew, fog, and rime with a high precision gravitation Lysimeter. Journal of Plant Nutrition and Soil Science, 170(1), 335-344. https://doi.org/10.1002/ jpln.200625002

Meissner R., Prasad M. N., Laing G., Rinklebe J. (2010). Lysimeter application for measuring the water and solute fluxes with high precision. Current Science, 99(5), 601-607.

Pintar M. (2003). Lizimetri v Sloveniji. V 14. Mišičev vodarski dan: zbornik referatov (str. 104-110). Maribor : Vodnogospodarski biro Maribor.

Schrader, F., Durner, W., Fank, J., Gebler, S., Pütz, T., Hannes,
M., Wollschläger, U. (2013). Estimating precipitation and actual evapotranspiration from precision lysimeter measurements. Procedia Environmental Sciences, 19, 543-552. https://doi.org/10.1016/j.proenv.2013.06.061

Šerjak, Š. (2019). Določitev napajanja vodonosnika s pomočjo lizimetra $v$ Klečah $v$ Ljubljani. Magistrska naloga. Naravoslovnotehniška fakulteta. https://repozitorij.uni-lj. si/IzpisGradiva.php?lang=slv\&id $=108920$

Šram D., Brenčič M., Lapanje A., Janža M. (2012). Prostorski model visečih vodonosnikov na Ljubljanskem polju = Perched aquifers spatial model: a case study for Ljubljansko polje (central Slovenia). Geologija, 55(1), 107-116. https://doi.org/10.5474/geologija.2012.008

Vižintin G., Souvent P., Veselič M., Čencur Curk B. (2009). Determination of urban groundwater pollution in alluvial aquifer using linked process models considering urban water cycle. Journal of Hydrology, 377(3), 261-273. https:// doi.org/10.1016/j.jhydrol.2009.08.025

von Unold, G., Fank, J. (2008). Modular Design of Field Lysimeters for Specific Application Needs. Water, Air, \& Soil Pollution, 8(2), 233-242. https://doi.org/10.1007/ s11267-007-9172-4

Vrzel J., Solomon K.D., Blažeka Ž., Ogrinc N. (2018). The study of the interactions between groundwater and Sava River water in the Ljubljansko polje aquifer system (Slovenia). Journal of Hydrolgy, 556, 384-396. https://doi.org/10.3390/ w11091753

Urbanc J., Jamnik B. (1998). Izotopske raziskave podzemne vode Ljubljanskega polja = Isotope investigations of groundwater from Ljubljansko polje (Slovenia). Geologija, 41(1), 355-364. https://doi.org/10.5474/geologija.1998.018

Urbanc J., Jamnik B. (2007). Porazdelitev in izvor nitratov v podzemni vodi Ljubljanskega polja. Geologija, 50(2), 468-475. https://doi.org/10.5474/geologija.2007.032

Zupanc V., Nolz R., Cepuder P., Bračič-Železnik B., Pintar M. (2012). Determination of water balance components with high precision weighing lysimeter Kleče. Acta agriculturae Slovenica, 99, 165-173. https://doi.org/10.2478/v10014012-0016-1 